\title{
Unmaking Masculine Determinacy: A Postmodern Challenge in Suzan-Lori Parks' Venus
}

\author{
Usa Padgate \\ Assistant Professor, Department of English, Faculty of Humanities, \\ Naresuan University, Phitsanulok, Thailand \\ usapadgate@gmail.com
}

\begin{abstract}
Venus, a play written by Suzan-Lori Parks, employs unconventional theatrical approaches in retelling the history of a 19th-century freak show attraction. This study examines how the critique of gender bias and sexual manipulations in Venus is explored and projected in ways that can be described as postmodern. Through the subversion of conventional forms and language, the blending of fact and fiction, the pastiches of both low and high generic and linguistic presentations, the liberating of a marginalized voice, and the revision of the philosophical premises that subordinate the female to the male order, the play questions the masculine determinacy inherent in social institutions and traditions and invites a conscious reconsideration of default meaning and truth.
\end{abstract}

\section{Keywords}

Venus - Suzan-Lori Parks - postmodernism - masculine determinacy

\section{$1 \quad$ Overture}

Venus is an experimental play written by American playwright and Pulitzer Prize winner Suzan-Lori Parks, first performed in 1996 and published in 1997. The play, based on the biographical records of South African Saartjie Baartman, narrates the struggles and humiliations that comprised the life of a 19th-century freak show attraction known as The Venus Hottentot who drew crowds by being made to expose her 'exotic' and phenomenally 
oversized behind and whose body became a subject of intrusive medical examinations both before and after her untimely death.

To tell a story of sexual exploitation conducted under the pretense of scientific advancement, Parks experiments with forms and presentations, turning heartbreak into an aesthetic quest and challenging the traditional claims of patriarchal assertions. In other words, the playwright makes the play work by unmaking certain characteristics that have worked in other more conventional plays. It is, therefore, this study's objective to investigate how the critique of gender bias and sexual manipulations in Venus is explored and projected in ways that can be described as 'postmodern.' The investigation employs as its conceptual framework the features that characterize postmodern fiction proposed by Geyh, Leebron and Levy in their 1998 anthology of postmodern American fiction, as illustrated in the next section.

The concept of 'postmodernism' is, admittedly, slippery in terms of both period and definition. In American literature, there is an attempt to point to the 196 os as representative of the phenomenon of postmodern American fiction, with the advent of experimental authors such as John Barth, Thomas Pynchon and Richard Brautigan (Geyh, Leebron, and Levy 1998, x). However, other scholars observe that postmodern elements can be found in works as old as 17th-century Don Quixote by Miguel de Cervantes (Barth 1984, 72; Foster 2008, 4), not to mention 5th-century B.C. Greek tragedian Euripides, whose exploration into the unconscious dimension of the human psyche earns him a seat of honor in postmodernism scholarship such as Eleni Boliaki (2000)'s study on Ancient Greek Drama, Postmodern Psychoanalysis and Fundamental Ambiguity: Euripides and Lacan and, more recently, Eleftheria Ioannidou (2017)'s publication of Greek Fragments in Postmodern Frames: Rewriting Tragedy $1970-2005$.

Likewise, a clear-cut definition of the term 'postmodernism' in literature defies a scholarly consensus, although the general sensitivity is that of skepticism towards the intellectual authority. For the purpose of the analysis in this study, however, the application of postmodernism in critical theory follows the definition provided by Geyh et al. (1998, x) as "a wide range of concepts, approaches, and positions in ongoing debates, the most significant of which concern the problematic relationship between the real and the unreal; the constructedness of meaning, truth, and history; and the complexities of subjectivity and identity." The discussion of the analysis, accordingly, is presented 
based on the framework suggested by the same scholars. The investigation of the stylistic, linguistic and thematic experimentation of Venus, therefore, is based on the following five unmaking traits of postmodern fiction: ${ }^{1}$ Breaking the Frame, Fact Meets Fiction, Popular Culture and High Culture Collide, Revisiting History, and Revising Tradition. The analysis is thus conducted and presented in this order.

The various postmodern approaches from which the study draws its conceptual agendas include the direction from Ihab Hassan's prompting of postmodernism as a heuristic scheme; hence, provisional and indeterminate in time and in structure (Hassan 1998). This is evident in the liberating views of history, race and gender as in Michael Bérubé's negation of historical determinism as part of the intellectual tool to tackle cultural contingencies (Bérubé 1998); Umberto Eco's similar emphasis on the ironic rethinking of the revisited past in place of a unitary history (Eco 1998); Bell Hooks' calls for the lifting of colonial paradigms that sustain white supremacist ideologies through the discourse of 'difference' and 'otherness' in reference to black identity (Hooks 1998), and Hélène Cixous' feminist criticism of the traditional pact between phallocentrism - which subordinates the feminine to the masculine - and logocentrism - which relegates a woman to a secondary status in an oppositional pair (such as activity-passivity) (Cixous 1998).

Also, various postmodern applications and interpretations are referred to in the analysis of Parks' play; for example, Jean Baudrillard's 'simulacrum' as a hyperreal - a model with no relation to any reality - as opposed to representation as the reflection of a profound reality (Baudrillard 1998), Donna Haraway's suggestion that monsters such as the Centaurs and the Amazons indicate the limits of community in Western notions as they disrupt social constructs (such as marriage) and boundaries (such as man-animal distinctions and male-female roles) (Haraway 1998), and Fredric Jameson's attention to the postmodern experience of space (through the practice of pastiche) and time (through the imitation of schizophrenia) that collapses the differentiation between the elite and the mass, rationalizes the ritual of replication and reinforces the logic of consumer capitalism (Jameson 1998).

1 Geyh, Leebron, and Levy (1998) identify six traits of postmodern American fiction. The sixth characteristic: Technoculture, however, does not apply in this study. The other five, in addition, are not always mutually exclusive in their distinction of postmodern features. History and tradition, for example, can be overlapping at points. Indications are given in the analysis where there are overlaps. 
In addition, the study grounds its arguments regarding the critique of language systems and gender disparities in Robin Lakoff's critical concept of Women's Language, which reflects how women are marginalized and rendered powerless by the ways they are expected to speak and the ways in which they are spoken of (Lakoff 1973), and of Luce Irigaray's critical tool of Mimesis, which resubmits female subjects to stereotypical views of women in order to bring these views into question and reorganize linguistic subjectivity, which excludes women, at a cultural level (Irigaray 1985, 1987).

By positing that postmodern devices empower Venus in probing and contesting the mechanisms of sexism, the study seeks to illustrate how the determinacy of the male order embedded in such inherently logocentric male spaces as the medical and judicial societies and the phallocentric philosophy that invariably subscribes to male superiority can be unmade.

By indicating the ironic distance and uncertainties derived from the play's playfulness, the study aspires to reflect that, as has been achieved through modernism's earnest approaches, the reality of stigmatized experiences can also be effectively, and 'truthfully,' perceived through the lenses of postmodernism.

\section{$3 \quad$ Breaking the Frame}

Fiction writing has been 'colonized' by authority that could be said to represent white male supremacist thinking in its conventionalized genres and generic boundaries, orderly linearity and gender-biased linguistic codes. In order to break away from this notion of 'authority', Hooks $(1998,629)$ campaigns for "decolonization as a critical practice" to achieve a transformative impact by means of, among other elements, styles of writing and chosen subject matters. In this spirit, postmodern writers explore, extend and explode the conventions of fiction, transcending both its limits and its possibilities in their innovative constructions of forms, narratives and language.

In contrast to the earnestness of modernism, postmodernism embraces playfulness, even when dealing with traumatized subject matters such as racism, sexism and misogyny. This irony creates distance, ruptures, and uncertainties that supposedly simulate how we experience reality.

Venus plays with forms, narrative and language. In contrast to the usual predictability of linear narrative, the play opts for non-linearity. The 31 scenes of the play are listed backwards and performed accordingly from Scene 31 to Scene 1, but, even so, not in an altogether 'predicted' backward chronology. The main plot is presented in an intermittently chronological fashion. A death announced at the beginning of the play triggers a flashback investigation into 
its cause. The first scene presented on the page (as well as on the stage) has the Chorus declare the death of The Venus Hottentot, ${ }^{2}$ thus recalling the Greek tragedies where the audience knows the ending before the actual actions of the play are set in motion while simultaneously parodying the classical plays in its projection of a tragic heroine whose physical absurdity (a large posterior) is considered both a flaw (a freak) and an attribute (female fertility) that lead to her tragic end.

Historical and medical 'extracts' displaying established social and scientific respectability are inserted throughout the play, as independent scenes or as fragments of certain scenes, thus disrupting the scenes and the scene sequence and often breaking down the plot of an intimate relationship between a man and a woman.

The first extract under the heading of "Footnote \#1" (Parks 1997, 24) appears during the seduction of The Venus Hottentot by The Brother at the end of Scene 30. The extract is proclaimed as a "Historical Extract" recording the year -1810 - and the nature of the performance of The Venus Hottentot who "bears her bottom." Towards the end of this proclamation, it also claims to "witness a very different performance" - the love scene. The seduction is, therefore, absurdly justified by history. By officiating the sexual exploitation with the formality of a historical record, the play employs a format monopolized by male authority to question, and ridicule, its justification.

The next extract labelled as "Footnote \#2" (Parks 1997, 28) in Scene 28 is an autopsy report of the body of The Venus Hottentot with details of The Baron Docteur's medical measurements and observations of The Venus Hottentot's internal organs. The extract precedes Scene 27 in which the public humiliation of The Venus Hottentot is kick-started after her meeting with The Mother-Showman, the master of the freak show. The physical abuse of The Venus Hottentot, therefore, is negotiated by the medical authority under patriarchal control.

On and on these extracts continue to interject. They are reminders of an inevitable tragic ending induced by scientific, medical and legal excuses to 'colonize' and take possession of the body of the Venus Hottentot both in life and in death.

The play, moreover, reminisces on the illusion of the theatre, as pointed out in William Shakespeare As You Like It: "All the world's a stage ... And one man

2 For reasons of clarity, in this paper the female protagonist is referred to in the analysis as "The Venus Hottentot" in order to differentiate the character from "The Hottentot Venus," an imposter that shows up later on in the play. Parks, however, employs a shorter term "The Venus" throughout to indicate the dialogues of her protagonist. 
in his time plays many parts" (Shakespeare 2009, 38). In Venus, the players are assigned multiple roles. The actor playing The Man also plays The Baron Docteur. The actor playing The Man's Brother likewise takes on the roles of The Mother-Showman and The Grade-School Chum. There is also a clear instruction to cast actors for the roles of The Father, The Mother, The Young Man, The Uncle, and The Bride-to-Be from those playing The Chorus. The fluid transition of these roles emphasizes the breakdown of conventional certainties and, in cases such as The Man's Brother/The Mother-Showman/The Grade-School Chum, gender boundaries.

In addition, the play, breaking free of the restrictions of form and style, is a conglomeration of linguistic presentations of prose and poetry, literature and science, and black vernacular and white authority, thus undermining the stylistic singularism that has bestowed certainty and superiority on the predictable language of science - generally deemed to be authoritative and male. The dialogues, in fact, are versed in refrains and rhythm, and, in many sections, read and sound not unlike a musical, a linguistic projection that cannot be more different from scientific prose:

The Man's Brother, later The Mother-Showman, laterThe Grade-School Chum

I regret to inform you that the Venus Hottentot iz dead.

There wont $b$ inny show tonite.

\section{The Negro Resurrectionist}

Diggidy-diggidy-diggidy-diggidy.

(Parks 1997, 3)

However, when actual poetry is performed, it is done with obvious irony, emphasizing the transiency and conspiracy of what is allowed as 'love.' A poetic stanza is repeated by different characters, both male and female, with slight variations, to profess both love and the deception of love, and to signal both the eternity of love and its temporality. Consequently, romance is overtaken by the hunger for ownership and self-interest although it is presented amorously in a poetic form. The certitude of romantic connotations of a love poem is then upset by the poem's physical and ideological contexts, thus staking its generic usage.

To start with, The Bride-to-Be's sentimental recital both disrupts and is disrupted by The Baron Docteur's matter-of-fact anatomical reports of the 
posthumous examination of The Venus Hottentot. The concurrent deliveries of the lines, poetic by The Bride-to-Be and scientific by The Baron Docteur, make for an unlikely duet characteristic of a postmodern creation while accentuating the stereotypical notions of female frivolity against male solemnity:

\section{The Bride-to-Be}

"My Love for you, My Love, is artificial

Fabricated much like this epistle.

Constructed with mans finest powrs

Will last through the days and the years and the hours." (REST)

\section{The Baron Docteur}

The mammae, situated exactly

Over the fourth and fifth ribs,

Were a full 6 inches apart at the inner edge of their bases ... (Parks 1997, 94)

Soon, nonetheless, The Baron Docteur expands his territory by laying claim to this feminine practice. When he repeats the stanza to The Venus Hottentot just a little while later, he claims ownership of the poem: "I made it up myself" (Parks 1997, 102). In so doing, he asserts a deceptive romantic design on a woman he will soon submit to torture and death in order to advocate his medical profession, thus revealing the artificiality of his love.

Based on Irigaray's illustrative concept of Mimesis, the aggression of intense feelings such as fear, envy, hope, hate and rejection is believed to be characteristic of a man. When a woman expresses these feelings, she is branded as being 'hysterical.' Ironically, feminine hysteria which "caricatures and deforms [masculine] language" (Irigaray 1985, 137) is commonly expected in a woman, and, therefore, in order to be 'feminine' a woman is obliged to mimic male aggression and risk being called hysterical. By imposing the stereotypical hysteria on a female character, Parks shows the "perversities" a woman "stoops to in order to 'please' and to live up to the 'femininity' expected of her" (Irigaray 1987, 59). By reflecting the same emotional qualities on a male character, Parks reverses the mimetic act by having The Baron Docteur mimic The Bride-to-Be's 'hysteria,' thus giving the options of either calling both or calling neither hysterical.

The use of poetic language is also contrasted both in tone and in form by the language of the judicial and medical fraternities that crowd the stage. When The Venus Hottentot is tried for indecent exhibition of her physique, a shameful act viewed to be under the influence of black magic, The Chorus of the 
Court assumes both the male authority addressing her demeaningly as "Girl" (Parks 1997, 75) and the white supremacy accusing her of bearing "God's bad mark" and of blackening-up "the honor of our fair country" (Parks 1997, 75).

That the so-called authority should take up legal proceedings over an assumption of black magic is in itself medieval and contradictory to the progressive image they are trying to project. The Venus Hottentot, on the other hand, refuses to be as headily presumptive and to involve others in the cat calls. Ironically, through the trial, The Venus Hottentot herself - the black female freak indicted of witchcraft and indecency - proves to be the most eloquent speaker and dignified presence in court, which eventually rules her out of all the charges made against her: "Please. Good good honest people. If I bear thuh bad mark what better way to cleanse it off? ... I came here black. Give me the chance to leave here white" (Parks 1997, 75-76). That she is acquitted of the legal charges on the premise of possible transformations unsettles the determinism of predestined attributes based on race and gender, if not the racial and sexual prejudices themselves.

In a similar way, the language and practice of the medical society employed at length in several sections of the play including the Intermission, serve not to lend but to loot epistemological credibility of such a gathering. The anatomical examination of The Venus Hottentot is shown to be merely a pretext for the male authority to take sexual pleasure of her:

\section{The Baron Docteur}

Vertex to

The top of shoulder in inches:

\section{The Chorus of the 8 Anatomists}

9.०.

The Baron Docteur is lost in thought. The Chorus of the 8 Anatomists waits patiently for him to resume, then, turning their backs to The Venus, they steal looks over their shoulders at her and jerk off (much like The Baron Docteur did in Scene 14).

(Parks 1997, 115-19)

3 As Robin Lakoff suggests in her 1973 essay "Language and Woman's Place," "girl” when used as a euphemistic address, connotes frivolity, immaturity and irresponsibility (Lakoff 1973, 61). 
As postmodern discourses often draw awareness to the experience of difference and otherness, "breaking the frame" is one tangible tactic to call attention to more elusive and abstract concepts. The invisible 'frame' governing the narrative in Venus is territorialized by the patriarchal order - male independence as opposed to female enslavement, male dynamic social integration as opposed to female subjected alienation, and, inevitably, male domination as opposed to female docility. The play's narrative is, in other words, 'colonized' by ideological determinants that favor patriarchy. The subversion of the conventional authorities of forms and language as seen in Venus, though never meant to alter the course of the story, facilitates an aesthetic challenge to the one-dimensional colonial paradigms of racial alienation and sexist ideologies of female subordination. By disrupting the chronological convention of the narrative with an unorthodox sequence of scene numbers and intermittent extracts, and obfuscating the gender expectations with a mimetic reversal of hysteria and verbal eloquence from a female character, the play invites a reconsideration of the determinacy of a conventional authority as well as empowers a realignment of ideological paradigms from a fresh view of the oppressed.

\section{4 \\ Fact Meets Fiction}

A concoction of fiction and non-fiction is not new to the American literary palette. From the early American novels, significant authors such as James Fenimore Cooper, Herman Melville, Mark Twain, etc., have conflated fictional representation with documentary fact. What makes the hybridity of fact and fiction in the work of post-World War II authors a postmodern trademark is its shift into "an aesthetic in its own right" (Geyh et al. 1998, 125). Authors experiment with formal combinations such as journalism and fiction claiming that subjectivity is a version of truth (for example, Truman Capote, Tim O'Brien, William T. Vollmann, Hunter S. Thompson, Tom Wolfe, Michael Herr, etc.), and memoir and fiction demonstrating that fictional constructions can help put real-life events in order (for example, Audre Lorde, Theresa Hak Kyung Cha, Gloria E. Anzaldúa, etc.). This uncertainty between fact and fiction extends the quality of 'truthfulness' that was traditionally attached to 'fact,' and, as a result, a story defined as 'truthful' may not be factual in the strictest conventional sense.

Venus is fictional in form, factual in origin and truthful in spirit. Parks sums up her artistic and thematic approach to the creation of the play: "Tell all the Truth but tell it slant," as Emily Dickinson says. With Venus my angle is this: 
History, Memory, Dis-Memory, Remembering, Dismembering, Love, Distance, Time, a Show" (Parks 1997, 166).

In spite of its fictional platform, Venus is unabashed in presenting factual information as 'factual information.' The narrative is interjected with insertions of historical, medical and judicial 'extracts' at irregular intervals, acting as supposedly authoritative footnotes to the narrative while poking fun at the attempts to justify morally dubious manipulations in a quest for knowledge.

Furthermore, the historical insertions heighten the irony of the veracity and the reality of 'facts.' For instance, when The Negro Resurrectionist declares "The year was 1810, three years after the Bill for the Abolition of the Slave-Trade had been passed in Parliament ..." (Parks 1997, 77) right after The Venus Hottentot's testimony in court, it is only to illustrate that the Bill could not in any way prevent post-colonial slavery in the forms of racial prejudice and discrimination.

The elements of fact and fiction in the play are further mingled by the fact that the subject of the play is a freak, a phenomenon that disrupts, by her mere existence, the boundary between the real and the unreal. Haraway $(1998,619)$ suggests that Western society shudders at monsters because they defy "the limits of community in Western imaginations." In the same way that the Centaurs of ancient Greece are said to pollute the boundary between the male human and animalism, a freak such as The Venus Hottentot is seen to confuse the human concept of modern identity. She is called by The Mother-Showman "STEPSISTER-MONKEY TO THE GREAT VENAL LOVE GODDESS," (Parks 1997, 35) highlighting both the relation and confusion between animality and divinity and collapsing the epistemological certainty of scientific categorization.

In addition, Venus presents a two-way conceptualization of fact and fiction: turning fact into fiction by means of biographical adaptation and then turning that fiction back into a different version of fact by means of simulacrum. The play originated from a 'real' story, and the biographical account of Saartjie Baartman serves as a backbone for creative embellishment of romance and betrayal. At the same time, Venus indulges the West's obsession with the exotic and feeds the occidental fantasy of the Hottentot with a ridiculous imitation, hence turning a play within a play - the masquerade of The Bride-to-Be as a Hottentot Venus - into a hyperreal farce. In order to reclaim the passion of her lover, The Young Man, who has been obsessing over the exoticism of The Venus Hottentot, The Bride-to-be resorts to disguising herself as a "Wild" Hottentot from "the darkest jungles" (Parks 1997, 132), who knows no means of human communication and speaks by clicking her tongue: "They click and cluck at each other" (Parks 1997, 133). 
This "simulation" of reality is defined by Baudrillard $(1998,634)$ as "the utopia of the principle of equivalence," in which models of the real are generated out of illusions and phantasms and without origin or reality. Whereas representation is the reflection of reality, simulation is a construct with no relation to any reality. The product of this constructed simulation is called a "simulacrum." Baudrillard describes four successive phases of constructing a simulacrum as follows: "It is the reflection of a profound reality; it masks and denatures a profound reality; it masks the absence of a profound reality; it has no relation to any reality whatsoever: it is its own pure simulacrum" (Baudrillard 1998, 635). In the same way that Disneyland (Baudrillard's famous example) was constructed from a utopia - detaching idealism from reality and turning that idealism into an existence of its own - the Hottentot is a brainchild of the West's imagination of an ideal 'wild' woman, and The Bride-to-Be's imposture as a Hottentot, therefore, is a simulacrum of The Venus Hottentot.

With the emphasis on the centrality of fact and fiction blending, Venus questions the inherent authority of fact derived from social institutions dominated by men and suggests ways in which facts have been confused with fiction and have been manipulated to justify brutality and murder. In addition, the simulacrum of The Venus Hottentot displayed by The Bride-to-Be makes fun not so much of the exoticism of a woman as it does of the delusion of a man. In the end, the blending of fact and fiction redefines the concept of truthfulness and points out, in the words of Kuhn $(1962,151)$ that 'neither proof nor error is at issue" since a fact can be a concept as deceptive as that of a Hottentot, and fiction can sometimes be truer than truth.

\section{$5 \quad$ Popular Culture and High Culture Collide}

The differentiation between high culture and mass, popular, 'low' culture is a relatively recent notion which emerged in the early twentieth century, partly to mark the widespread, hence 'mass,' social, economic and technological changes in America and partly to draw attention to the rebellious artistic movements against the established forms of high modernism of the previous century - movements that came to be called collectively postmodernism. While high modernist artists experiment with such concepts as abstract expressionism, cubism, minimalism, etc., as an aesthetic albeit scandalous break from traditions, the postmodern movements erode the separation between elitism and populism by utilizing materials from popular culture in combination with scholarly references to convey linguistic and metaphoric 
meanings. Postmodernists, in Jameson's words, "no longer 'quote' such 'texts' as a Joyce might have done, or a Mahler; they incorporate them, to the point where the line between high art and commercial forms seems increasingly difficult to draw" (Jameson 1998, 655). The realization of this 'incorporation' is made through a practice called 'pastiche,' which Jameson describes as the postmodern experience of space "to imitate dead styles, to speak through the masks and with the voices of the styles in the imaginary museum" (Jameson 1998, 658).

Venus is a pastiche of styles and voices. The drama of the play is both suspended and heightened by the reports from the medical and historical extracts as already illustrated in the previous section. In addition, in a characteristic pastiche spirit, The Venus Hottentot appears in Scene 3 - after Scene 4 in which The Bride-to-Be disguised as a Hottentot Venus succeeds in seducing The Young Man, and before Scene 2 in which The Negro Resurrectionist has just been bribed into turning in The Venus's body for maceration - to recite 'A Brief History of Chocolate.' This piece of recital also represents a pastiche of both fact and folklore concerning the history and geography of western colonialism as well as of the pain and pleasure of love, all of which constitute The Venus Hottentot herself. Inciting divine 'Love' as the origin of earthly chocolate, the history of chocolate begins with the breakdown of the separation between the immortal and the mortal - the high and the low: "As an act of Love one God gives to the people a little shrub that had, until then, belonged only to the Gods. This was the cacao tree" (Parks 1997, 155).

Dark and sweet in appearance, heathen and colonial in origin, sensual and aphrodisiac in character, chocolate metaphorizes The Venus Hottentot, as Padgate $(2019,206)$ suggests. Negating the official, unified and authoritative - hence, male-dominated - story of chocolate, The Venus Hottentot rememorizes its history by patching together her own story of colonial ties: "In Europe the church wages a campaign against chocolate on the grounds that it was tainted by the character of its heathen inventors," (Parks 1997, 155) of romantic fantasies: "it has become the practice to present a gift of chocolates when professing Love," (Parks 1997, 156) and of physical stakes: "While chocolate was once used as a stimulant and source of nutrition it is primarily today a great source of fat, and, of course, pleasure" (Parks 1997, 156).

Although The Venus Hottentot conforms to the expectations of a good colony in her obedience and provision of physical abundance, she makes use of the colonial tools to negotiate her share of a man's affection, thus subscribing the colonial - male - power to her emotional direction. For this reason, 
The Venus Hottentot is not entirely passive as a 'colony' but able to strike back when she wants to. The physical territory of The Venus Hottentot is claimed and exploited by a succession of male figures in their economic and professional pursuits. She almost consistently plays the role of a noble savage intelligent, independent and unresistant. Open to new intrigues and proud of her natural resources, she even encourages the colonization of her body by calling The Baron Docteur "Columbus II" (Parks 1997, 104). Also, she develops a taste for chocolate, not in its original pagan form but as a processed delicacy of European civilization. Chocolate then becomes a means by which she is enslaved, pacified and bribed by The Baron Docteur: "Here. Yr favorite: Chockluts. Have some" (Parks 1997, 105). By ways of this 'enslavement,' nevertheless, she acquires French, her second foreign tongue, the first being English, and in turn commands both foreign languages in ways that challenge the colonizer's expressed desire to reclaim his status:

\section{The Baron Docteur}

Ive got a wife. You've got a homeland and a family back there.

\section{The Venus}

I don't wanna go back inny more.

I like yr company too much.

Besides, it was a shitty life.

(Parks 1997, 105)

Refusing to be decolonized, she ignores her lover's conservative articulations and mixes the courtly French with the colloquial English, bringing together the two western imperial powers and monopolizing the man's emotional dependency and genetic descendancy by becoming twice pregnant with his child as opposed to the man's 'childless' wife (Parks 1997, 107).

By combining forms of generic and linguistic presentations that are of both high and low cultural status, Venus breaks down "the barrier that has been erected between art and enjoyability" (Eco 1998, 624) and exhibits how colonial manipulations can be exploited by both the colonizer and the colonized. The formality of high culture provides a pretext for the colonizer to proclaim his superiority, which can then be disrupted by the pastiche of other, more lowbrow styles. The result exposes the colonizer's discrepancy - if not outright hypocrisy - and divided power as well as the colony's gift for assimilation and readiness to strike back with familiarized western weapons. 
Jameson $(1998,656)$ points out two significant features of how postmodernism expresses "the inner truth of that newly emergent social order of late capitalism": pastiche and schizophrenia. While pastiche explores the postmodern experience of space as discussed in the previous section, schizophrenia characterizes the postmodern experience of time by fragmenting time into "a series of perpetual presents" (Jameson 1998, 662). In other words, postmodern writing revisits the past "in the belief that the past - or some version of it - remains an active and transforming force in the present" (Geyh et al. 1998, 293). This is done in various ways. One approach characteristic of postmodern American authors is to retell history from a transformed viewpoint in order to retrieve a story that has been marginalized and bring it to center stage. The story of a minority individual retold by a minority author is a case in point. While Saartjie Baartman originated in South Africa, Venus was born out of gossip. In Parks' own words, "I first heard about the woman called the Hottentot Venus at a cocktail party. Liz Diamond was talking about her and I was eavesdropping. (Parks 1997, 166)"

As in retelling the history of chocolate, fictionalizing the life of a 'real' freak show sensation invites a reconsideration of the constructedness of history, both mainstream and marginalized. Juxtaposing The Venus Hottentot's simple, personal and fragmented account of her life - a female subjectivity represented by a female character: "I was born near the coast, Watchman. Journeyed some worked some ended up here ..." (Parks 1997, 159) - with The Negro Resurrectionist's official and unitary 'historical' report - a male authority represented by a male character: "Early in the 19th century a poor wretched woman was exhibited in England under the appellation of The Hottentot Venus ..." (Parks 1997, 159) - stresses the complexity of subjectivity and identity that transcends the domination of official history.

Another approach to display the fragmentation of time is the deconstruction of linear historical narratives in order to endorse postmodernism's multiplicity and suggest that "our beliefs and practices are culturally 'contingent,' subject to ongoing revision, bound to no historical determinism" (Bérubé 1998, 599). Venus decenters the concept of chronology through an obsessive use of numbers in a mixed fashion of conventionality and unconventionality. When used conventionally, the numbers often depict the language of science and authority. In addition to the lengthy and precise measurements spelled out by The Baron Docteur and the medical society as illustrated earlier in the article, numbers are called out by The Negro Resurrectionist to indicate a sequence of evidence such as footnotes and court witnesses; for example, "Footnote \#8 Definition: Medical: Maceration ..." (Parks 1997, 120). 
Also, The Negro Resurrectionist calls out numbers in leaps, yet still in sequence, to suggest a passage of time; for example:

Town A! Town B! Town C! Town E!

Town 25! Town 36! Town 42! Town 69! (Parks 1997, 58)

When used by female characters, numbers underwrite the monetary gains in exchange of a female body, as can be seen when The Mother-Showman is counting the money she has collected from exhibiting her ' 9 Human Wonders':

\section{The Mother-Showman}

10-20-30-40

$50-60-70-80-90$ :

We didn't do too bad today.

Hottentot, yr a godsend! (Parks 1997, 40-41)

However, when used unconventionally such as in the backward numeration of the scenes, the numbers suggest the indeterminacy of time and history. Ironically, both The Negro Resurrectionist and The Baron Docteur take part in emphasizing this problematized relation to time. When The Negro Resurrectionist counts down the scenes in his common English tongue from 31 to 14, The Baron Docteur continues seamlessly by counting down from Quatorze [Fourteen] to Un [One] in his sophisticated French (Parks 1997, 101-02). The combination of different languages and supposedly different locales of the characters only adds to the plurality of temporal and historical possibilities.

As Eco $(1998,622)$ opines, since the past "cannot really be destroyed, because its destruction leads to silence, [it] must be revisited; but with irony, not innocently." Venus unsilences the buried history of a marginalized voice, reconstructs it provocatively in a mixed sequence of past and present, and lets the audience work out their refreshed relation to the irony of 'official' history.

\section{$7 \quad$ Revising Tradition}

Traditionally, the solidarity between logocentrism and phallocentrism makes all conceptual hierarchy subject to man. This can be seen, as Cixous $(1998,853)$ 
points out, in the gender-coded oppositions of "Activity/Passivity, Sun/Moon, Culture/Nature, Day/Night, Father/Mother, Head/Heart, Intelligent/Palpable, Logos/Pathos," of which the second item is traditionally secondary in status and invariably prescribed as 'female,' as opposed to the 'male' connotation in the first item of each pair. Female passivity, consequently, is a premise as readily acceded as male authority. Continuing in this line of rationale, Cixous concludes, "Either woman is passive or she does not exist" (Cixous 1998, 584). This problematic definition of female identity is also famously addressed by Simone De Beauvoir $(1970,223)$. "Truth, Beauty, Poetry - she is All: once more all under the form of the Other. All except herself." To the figures of authority in Venus, The Venus Hottentot is romanticized as "True Love" (Parks 1997, 140), animalized as the "Missin Link" (Parks 1997, 42) and mythicized as "the Goddess Venus H." (Parks 1997, 66). In short, she is, to them, a girl, a freak, a goddess; all except herself.

However, Parks does not portray her female protagonist as a picture of passivity. In spite of overwhelming restraining forces imposed by others, The Venus Hottentot emerges to be surprisingly active inside and out. Physically, she is seen to be "vigorous" at domestic chores (Parks 1997, 11) and insatiable in bed. Intellectually, she proves to be engaged in learning and suggests ways to improve her performances with such sophisticated means as poetic recitals - a 'culture' contrasting so starkly with her perceived 'nature' that it is dismissed straight away by The Mother-Showman. When she has been cheated out of her fees, she makes plans to set up a business of her own. When she is threatened with being sent home against her will, she employs the tools of her accusers to convince the authority to free her of all the charges, admitting to being baptized as a Christian and conceding to the dominance of white supremacy. That her dreams and wishes are thwarted by the circumstances of the time and place she is in does not diminish the manifestation of the active mind and body she possesses.

On the other hand, an established patriarchal authority such as the court of justice is shown to be conceptually constricted by its own interpretation of mainstream religious tradition and constitution. The Mother-Showman only has to show a certificate of baptism of The Venus Hottentot as proof of her decent guardianship to acquit herself of the legal and moral suspicion of the court. When The Venus Hottentot herself is finally released, the court once again invokes religion as a determinant: "It is clear shes got grand plots and plans to make her mark and her mint by playing outside the bounds so that we find her person much depraved but she sez her show is part of Gods great plan and we buy that" (Parks 1997, 78). 
Formally, Venus transforms an old story and prose traditions into a new form of dramatic performance, doing away with rules of punctuations, capitalization and line division, mixing languages, genres and registers, and inventing a "road map" to communicate meanings on and off the stage, and on and out of the pages. Parks details her "slightly unconventional theatrical elements" in "Author's Notes." For example:

- $\quad$ (Rest)

Take a little time, a pause, a breather; make a transition.

- A Spell

An elongated and heightened (Rest). Denoted by repetition of figures' names with no dialogue. Has sort of an architectural look:

\section{The Venus}

\section{The Baron Docteur}

... (Parks 1997, Author's Notes)

Implementing these codes creates a new possibility of 'reading' a play. Tensions are made readable, and oppression weighs down by long stretches of words as opposed to silence signified by the agreed upon theatrical codes. For example, when The Baron Docteur finds out that his lover is pregnant, he rants about the risk of losing his social status and coerces her into having an abortion. All the while, the silence of The Venus Hottentot and the few words that she says signal her subordination, verbal as well as physical - an abject condition that may not win her the game of love but can certainly reveal a man's moral weakness and hypocrisy as much as a woman's inner strength and decency:

\section{The Baron Docteur}

God. Is there anything we can do about it.

Ive a wife. A career.

A reputation. Is there anything

We can do about it we together in

the privacy of my office.

Ive got various equipments in here

we could figure something out.

\section{The Venus}

The Venus

The Venus 


\section{The Venus}

Where I come from

its cause for celebration.

\section{The Baron Docteur}

A simple yes or no will do, Girl. (Rest)

\section{The Venus}

Yes. (Parks 1997, 128-29)

Traditions can be rigorous, but they are not immune from transitions. As Hassan $(1998,586)$ puts it, "Traditions develop and suffer a seachange." Teasing the traditional division between male activity and female passivity both in the physical and intellectual sense and communicating meanings in innovative ways, Venus demands a conscious revision of the philosophical premises that subordinate the feminine to the masculine order. The sexual exploitations and inhuman violations - the abortions and the eventual abandonment that leads to The Venus Hottentot's death - committed by the Baron Docteur leave one to wonder if the traditional superiority of the Head over the Heart, Logos over Pathos, and eventually Man over Woman should not be revised.

Encore

By investigating how the critique of gender bias and of sexual manipulations in Suzan-Lori Parks' experimental Venus is projected via five postmodern approaches suggested by Geyh et al. (1998), the play is shown to unmake the determinacy of the male order deeply rooted in social establishments and authorities ranging from clearly marked logocentric male spaces such as the medical and judicial communities of the 19th century to the less visible male-female distinction encouraged by the phallocentric philosophy of canonical oppositions.

In "Breaking the Frame," the subversion of conventional theatrical forms and language in Venus is shown to facilitate an aesthetic challenge to the colonial paradigms of racial alienation and sexist ideologies of female subordination.

In "Fact Meets Fiction," the blending of drama and scholarly extracts in the play and the paradox of the simulacrum of a female body that is both ridiculed and idealized are analyzed to suggest the boundary disruption between the real and the unreal as well as a redefinition of truthfulness and to question the 
inherent authority of fact derived from and manipulated by social institutions controlled by men.

In "Popular Culture and High Culture Collide," both high and low forms of generic and linguistic presentation are shown to feature in the play in the form of colonial manipulations where the formality of high culture provides a pretext for the colonizer to proclaim his superiority, which can then be contested by the pastiche of other, more lowbrow styles.

In "Revisiting History," the analysis shows a marginalized voice unsilenced to retell her side of the "official" history specifically of herself, and thematically of her race and gender in fragmented linearity and backward scene numeration.

Finally, in "Revising Tradition," the play is shown to invite a conscious reconsideration of the philosophical premises that subordinate the feminine to the masculine order such as the traditional division between male activity and female passivity both in the physical and intellectual sense.

In short, this study serves to review, within the scope of the play Venus, the masculine determinacy protected by such influential social institutions as the law, science and medicine and empowered by such widespread social practices as colonialism, racism and sexism and to examine how it is unsettled by a girl - a freak and a goddess all in herself.

\section{References}

Barth, John. 1984. The Friday Book: Essays and Other Non-Fiction. London: The John Hopkins University Press.

Baudrillard, Jean. 1998. "Simulacra and Simulation." In Postmodern American Fiction: A Norton Anthology, edited by Paula Geyh, Fred G. Leebron, and Andrew Levy, 631-37. New York: W. W. Norton \& Company.

Bérubé, Michael. 1998. “Just the Fax, Ma'am: Or, Postmodernism's Journey to Decenter." In Postmodern American Fiction: A Norton Anthology, edited by Paula Geyh, Fred G. Leebron, and Andrew Levy, 595-6o3. New York: W. W. Norton \& Company.

Boliaki, Eleni. 20oo. "Ancient Greek Drama, Postmodern Psychoanalysis and Fundamental Ambiguity: Euripides and Lacan." PhD diss., Syracuse University. Cixous, Hélène. 1998. "Sorties: Out and Out: Attacks/Ways Ou/Forays." In Postmodern American Fiction: A Norton Anthology, edited by Paula Geyh, Fred G. Leebron, and Andrew Levy, 583-85. New York: W. W. Norton \& Company.

De Beauvoir, Simone. 1970. The Second Sex. New York: Bantam.

Eco, Umberto. 1998. "Postmodernism, Irony, the Enjoyable." In Postmodern American Fiction: A Norton Anthology, edited by Paula Geyh, Fred G. Leebron, and Andrew Levy, 622-24. New York: W. W. Norton \& Company. 
Foster, Thomas C. 2008. How to Read Novels Like a Professor. New York: HarperCollins. Geyh, Paula, Fred G. Leebron, and Andrew Levy. 1998. Postmodern American Fiction: A Norton Anthology. New York: W. W. Norton \& Company.

Haraway, Donna. 1998. "A Cyborg Manifesto: Science, Technology, and SocialistFeminism in the Late Twentieth Century." In Postmodern American Fiction: A Norton Anthology, edited by Paula Geyh, Fred G. Leebron, and Andrew Levy, 6o3-22. New York: W. W. Norton \& Company.

Hassan, Ihab. 1998. "Toward a Concept of Postmodernism." In Postmodern American Fiction: A Norton Anthology, edited by Paula Geyh, Fred G. Leebron, and Andrew Levy, 585-95. New York: W. W. Norton \& Company.

Hooks, Bell. 1998. "Postmodern Blackness." In Postmodern American Fiction: A Norton Anthology, edited by Paula Geyh, Fred G. Leebron, and Andrew Levy, 624-31. New York: W. W. Norton \& Company.

Ioannidou, Eleftheria. 2017. Greek Fragments in Postmodern Frames: Rewriting Tragedy 1970-2005. Oxford: Oxford University Press.

Irigaray, Luce. 1985. This Sex Which Is Not One. Translated by Catherine Porter and Carolyn Burke. New York: Cornell University Press.

Irigaray, Luce. 1987. Speculum of the Other Woman. Translated by Gillian C. Gill. New York: Cornell University Press.

Jameson, Fredric. 1998. "Postmodernism and Consumer Society." In Postmodern American Fiction: A Norton Anthology, edited by Paula Geyh, Fred G. Leebron, and Andrew Levy, 654-63. New York: W. W. Norton \& Company.

Kuhn, Thomas S. 1962. The Structure of Scientific Revolutions. Chicago: University of Chicago Press.

Lakoff, Robin. 1973. "Language and Woman's Place." Language in Society 2 (1): 45-80.

Padgate, Usa. 2019. “Women's Language and a Freak: A Display of Gender Disparity in Suzan-Lori Parks' Venus." Journal of Human Sciences 20 (2): 195-224.

Parks, Suzan-Lori. 1997. Venus. New York: Theatre Communications Group.

Shakespeare, William. 2009. As You Like It: The Cambridge Dover Wilson Shakespeare Volume 3. New York: Cambridge University Press. 